\title{
PENERAPAN METODE DAKWAH MUJADALAH DALAM MEMBENDUNG RADIKALISME DI INDONESIA
}

\author{
Agung Teguh $P$ \\ STID Al-Hadid, Surabaya \\ agung_atp@yahoo.co.id
}

\begin{abstract}
Abstrak: Gerakan Islam radikal masih menjadi masalah di Indonesia. Terdapat berbagai varian gerakan Islam radikal, mulai dari yang bersifat terorisme, transnasionalisme, sampai dengan wahabisme. Secara keseluruhan kelompok Islam radikal memiliki metode dakwah yang khas, yaitu indoktrinasi, cenderung kaku dan tekstual dalam memahami Al-Qur'an dan hadis, kekerasan dan pemaksaan dalam pelaksanaan ajarannya, menganggap kelompoknya yang benar, dan tidak jarang memprovokasi. Saat dipraktekkan di Indonesia seringkali mengalami benturan dengan negara dan masyarakat, baik dengan sesama muslim dan juga nonmuslim. Studi ini mendeskripsikan penerapan metode dakwah mujadalah dalam rangka membendung dakwah radikalisme di Indonesia. Metode studi adalah kualitatif pustaka. Hasil studi menunjukkan bahwa metode mujadalah memiliki keunggulan bersifat dialektika dan bisa membongkar pemikiran Islam radikal yang bersumber dari kekeliruan memahami ayat-ayat Allah. Dalam penerapannya, metode mujadalah dapat menyasar kepada para pelaku radikalis maupun umat Islam yang terpengaruh dengan pemikiran radikal. Teknisnya dengan mencoba mempertanyakan kembali (dialektika) dan menggunakan logika-logika dasar serta pengetahuan ilmiah dalam membongkar kesalahan berpikir pemahaman radikal, khususnya terkait ayat-ayat jihad dan perang, penegakan syariat Islam, dan sebagainya. Aspek yang juga perlu diperhatikan adalah etika dalam komunikasi dakwah, agar dakwah dengan metode mujadalah dapat berhasil.
\end{abstract}

Kata Kunci: metode dakwah mujadalah, Islam radikal, radikalisme di Indonesia

The Implementation of Da'wah Method of Mujadalah in Stemming Radicalism in Indonesia. Abstract: The radical Islamic movement remains a problem in Indonesia. There are various radical Islamic movements, from terrorism, trans-nationalism to wahhabism. As a whole, radical Islamic groups have typical methods of da'wah: indoctrination, tendency of being rigid, being textual in interpreting Al Qur'an and hadist, violence and coercion in the performance of its teachings, believing their groups are the most righteous, and frequently provoking. While being practised in Indonesia, it frequently clashes with government and society, both with Moslems and non-Moslems. This study describes the implementation of Mujadalah as da'wah method in stemming radicalism in Indonesia. It applies qualitative library research. It results that this method has excellencies in dialectical form and exposing radical Islamic thinking which misunderstanding God's verses. In its implementation, this method can target to radicalists and Moslems affected by radical thoughts. Its technique is by dialectically re-questioning and using basic logic thinking and scientific knowledge in exposing their misunderstanding, especially related to the verses of jihad, warfare, enforcement of Sharia and so forth. An aspect concerned in this method is the ethic of da'wah communication, so that da'wah with mujadalah can be successfully conducted.

Key words: Mujadalah da'wah method, radical Islamic thinking, radical Islamic movement in Indonesia 


\section{Pendahuluan}

Rentetan peristiwa teror dan bom yang ada di Indonesia kembali memunculkan isu radikalisme atau Islam radikal. Peristiwa pengeboman tiga gereja yang terjadi di Surabaya, pelakunya adalah satu keluarga yang melibatkan ayah, ibu, dan dua anak usia sekolah dasar. Disusul pengeboman di depan markas kepolisian resor kota (Mapolresta) Surabaya yang pelakunya adalah suami istri dan membawa anak kecil.. ${ }^{1}$ Selain itu penangkapan terduga terorisme oleh pihak kepolisian juga terjadi di beberapa daerah, seperti di Sumedang dan Bandung Jawa Barat di mana detasemen khusus (Densus) dan Kepolisian Daerah (Polda) Jawa Barat menangkap beberapa anggota Jamaah Ansharut Daulah (JAD) yang diduga terlibat dalam aksi teror bom panci di Kampung Melayu, Jakarta Timur. ${ }^{2}$ Peristiwa terbaru adalah penusukan Menteri Koordinator Politik, Hukum, dan Keamanan (Menkopolhukam) Wiranto, yaitu saat melakukan kunjungan kerja di Pandeglang Banten. Penusukan tersebut dilakukan oleh Abu Rara dan mengakibatkan Menkopolhukam harus dioperasi di Rumah Sakit Gatot Subroto. Pelaku dalam melakukan aksinya tidak sendirian tetapi juga melibatkan istrinya, bahkan anak dari pelaku juga didoktrin untuk berbuat yang sama. $^{3}$ Gerakan radikalisme terorisme di Indonesia telah mengalami perubahan arah, kalau sebelum tahun 2010 arah teror adalah orang asing dan fasilitas-fasilitas asing yang dianggap musuh Islam, tetapi sejak tahun

\footnotetext{
1 "Serangan bom di tiga gereja Surabaya: Pelaku bom bunuh diri 'perempuan yang membawa anak'," $B B C$ News Indonesia, diakses 8 Februari 2020 https://www.bbc.com/indonesia/indonesia-44097913 2 Sindo News.com, diakses 8 Februari 2020 https://index.sindonews.com/index/9/30?t=2018-0812

3 Devina Halim, "Polri: Penusuk Wiranto Menyuruh Anaknya Melakukan Serangan ke Polisi," Kompas.com,
}

2010 mereka beralih kepada aparat-aparat kepolisian yang dianggap sebagai figur penghalang perjuangan mereka. ${ }^{4}$

Di samping model gerakan radikalisme berupa teror, muncul juga gerakan-gerakan yang mengatasnamakan pemurnian ajaran Islam dan semangat kembali ke Al-Qur'an dan As-Sunnah. Mereka melakukan kampanye secara masif bahwa umat Islam kalau ingin kembali jaya harus menggunakan sistem khilafah seperti masa kejayaan khilafah Turki Ustmani. Kehancuran dan keterpurukan umat Islam di segala bidang saat ini karena meninggalkan sistem khilafah. Mereka mengatakan sistem khilafah yang diterapkan mulai zaman Nabi sampai zaman Turki Ustmani terbukti mampu membuat Islam jaya dan menjadi kekuatan yang ditakuti oleh umat non-Islam. Selain itu muncul pula kelompok Islam yang sangat puritan-pemurnian dengan nuansa ideologis yang kuat berdasarkan kelompok ideologis Ikhwanul Muslim yang didirikan Hasan al-Banna dan diteruskan oleh Sayyid Qutub, sekalipun belakangan mengalami beberapa modifikasi. Hal ini tampak terlihat dari banyaknya varian Islam neofundamentalis-salafi radikal di Indonesia yang lebih bersifat antikekerasan ketimbang pro pada jalan kekerasan dan revolusioner ala Hasan Al-Banna. ${ }^{5}$ Ada juga yang menawarkan bahwa pola hidup yang islami ala Rasulullah, sehingga harus memakai pakaian seperti Nabi bagi yang lelaki dan berjenggot, sementara yang perempuan

diakses $25 \quad$ Desember 2019 https://www.kompas.com/nasional/read/2019/2019/ 10/17/18091901/polri-penusuk-wiranto-menyuruhanaknya-melakukan-serangan-ke-polisi.

4 Tim Kompas, "Satu Dekade Polisi Jadi Sasaran Teror," Koran Kompas, edisi Kamis, 14 November 2019.

5 Greg Fealy, Jejak Kafilah: Pengaruh Radikalisme Timur Tengah di Indonesia (Bandung: Mizan, 2005), 12. 
memakai cadar, mereka yang tidak melaksanakan sunnah rasul dianggap sesat dan bukan dari golongan mereka. ${ }^{6}$ Kelompok-kelompok ini memang tidak seekstrem kelompok garis keras yang melakukan teror tetapi kelompok ini menyerang pemahaman atau pemikiran sesama muslim dan terkadang mereka menganggap yang bukan kelompoknya adalah sesat.

Melihat gejala tersebut pemerintah Indonesia akhirnya pada tahun 2017 mengeluarkan sikap dengan menerbitkan Peraturan Pemerintah Pengganti UndangUndang (Perppu) Nomor 2 tahun 2017 yang mengubah UU Nomor 17 Tahun 2013 tentang Organisasi Kemasyarakatan. Dampak dari Perppu tersebut beberapa ormas Islam yang mengindikasikan menyebarkan paham kebencian terhadap keutuhan NKRI dan Pancasila, dengan citacita pendirian khilafah islamiah atau pendirian negara Islam, dipaksa untuk membubarkan diri. Gerakan radikal itu merupakan kelompok yang ingin mengganti dasar dan ideologi negara dengan melawan aturan. Menurut Mahfud MD., gerakan tersebut berupaya merusak cara berpikir generasi baru. Gerakan itu menyebabkan anak-anak muda menganggap bernegara dan kontitusi yang diterapkan salah, "Bahwa kebetulan ada Islam karena radikalnya, bukan Islamnya."7 Juga disampaikan oleh Karyono Wibowo direktur Indonesia Publik

6 Mila, "5 Sunnah Rasulullah Dalam Berpakaian," Islampos, diakses 21 November 2019. www.islampos.com/75509-75509/amp/

7 "Mahfud MD Sebut Radikalisme tak identik dengan agama tertentu" CNN Indonesia, diakses 31 Desember 2019.

https://m.cnnindonesia.com/nasional/201910312004 09-20-444673/mahfud-md-sebut-radikalisme-takidentik-dengan-agama-tertentu
Institut (IPI) sebetulnya gerakan radikalisme tidak hanya ada pada Islam tetapi juga ada di agama-agama selain Islam sehingga perlakuan terhadap penindakan gerakangerakan radikal selain Islam juga ditindak dan diperlakukan yang sama dengan gerakan Islam radikal, misal di berbagai daerah juga ada radikal Kristen atau radikal Nasrani. ${ }^{8}$ Sejatinya Islam tidak pernah mengajarkan terorisme. Apa yang ditangkap masyarakat dunia adalah apa yang didefinisikan dalam media-media terutama yang dari Barat terkait gerakan kelompok radikal dan teroris yang diidentikkan dengan Islam. Sementara jika menyebut gerakan radikal fundamentalis dan penggunaan kekerasan (terorisme) sebenarnya tidak hanya dilakukan oleh kelompok yang mengaku beragama Islam, tetapi juga dilakukan oleh kelompok agama lain atau etnis tertentu, seperti gerakan Tamil di Srilangka, militan Hindu di India, IRA (kelompok bersenjata Irlandia Utara), militan Yahudi sayap kanan, sekte kebatinan di Jepang, dan sebagainya. ${ }^{9}$

Sebelumnya dua organisasi besar di Indonesia yaitu Nahdlatul Ulama (NU) dan Muhammadiyah mengeluarkan seruan yang sama kepada seluruh anggotanya tentang bahayanya gerakan Islam Transnasionalisme. Muhammadiyah melalui SKPP Muhammadiyah Nomor: 149/Kep/I.0/B/2006 untuk menyelamatkan perserikatan dari infiltrasi partai politik. ${ }^{10}$ Bagi Muhamadiyah kelompok Islam

\footnotetext{
${ }^{8}$ Karyono Wibowo, "Selain di Islam Kelompok Radikal Juga Ada di Agama Lain," merdeka.com, diakses 19 Februari 2018. https://m.merdeka.com/peristiwa/selain-di-islamkelompok-radikal-juga-ada-di-agama-lain.html

9 Sun Choirol Ummah, "Akar Radikalisme Islam di Indonesia," Humanika, Vol. 12 No. 1 (2012), 112-124. https://doi/org/10.21831/hum.v12i1.3657

10 "SKPP Muhammadiyah No. 149/Kep/I.0./2006 tentang Kebijakan Pimpinan Pusat Muhammadiyah
} 
Transnasional tidak nampak tetapi efeknya sangat luar biasa. Kader-kader Muhamadiyah yang tidak kuat pola pikir dan pemahamannya akan dibuat ragu dan diajak keluar dari Muhamadiyah, dan yang lebih parah aset-aset Muhamadiyah banyak yang diambil alih ke kelompok tersebut tanpa disadari oleh Muhamadiyah. ${ }^{11}$ Begitu pula NU mengeluarkan fatwa bahwa Khilafah Islamiyah tidak mempunyai rujukan teologis baik di dalam Al-Qur'an maupun hadis. Pengurus Besar NU mengingatkan bahwa ideologi transnasional berpotensi memecah belah bangsa Indonesia dan merusak amaliyah diniyah umat Islam. ${ }^{12}$ Sebenarnya ada kesamaan makna yang dimaksud oleh pemerintah dan dua ormas besar tersebut, bahwa gerakan terorisme di Indonesia dan gerakan Islam transnasionalisme adalah gerakan Islam radikal. Istilah Islam transnasionalisme mengacu pada istilah ideologi transnasional, yang merujuk pada ideologi keagamaan lintas negara yang sengaja diimpor dari luar dan dikembangkan di Indonesia. ${ }^{13}$ Dengan doktrin sebagai gerakan dakwah Islam amar makruf nahi mungkar dan mengamalkan syariat Islam maka banyak warga Muhammadiyah dan NU yang terkecoh dengan gerakan Islam transnasional, yang membawa pemikiran Islam radikal. Menurut Zuli Qodir mulai saat ini, Muhammadiyah dan NU harus benarbenar menyadari, sebab Gerakan Islam transnasional yang salah satunya berwujud

Mengenai Konsolidasi Organisasi dan Amal Usaha Muhammadiyah." Muhammadiyah.or.id www.muhammadiyah.or.id/id/download-peraturan7.html

${ }^{11}$ Zuly Qodir, Syariah Demokratik: Pemberlakuan Syariah Islam di Indonesia, (Yogyakarta: Pustaka Pelajar, 2004) 56.

${ }^{12}$ Amsar A Dulmanan, "Pendidikan Karakter: Menjadi NU, Menjadi Indonesia," NU.or.id, gerakan tarbiyah adalah gerakan politik praktis yang berkedok dakwah adalah sangat berbahaya, karena bukan tidakmungkin akan melakukan pengambil-alihan atas amal usaha milik organisasi. ${ }^{14}$

Jadi secara garis besar gerakan Islam radikal ada yang menjurus pada perilaku terorisme ada yang tidak. Ada gerakan Islam radikal yang mencoba menerapkan syariat-syariat Islam secara tekstual, kaku, keras, dan menekankan simbol-simbol Islam dibanding dengan pelaksanaan Islam yang secara substansi tetapi dalam pelaksanaannya mereka tidak melakukan teror dan perampasan hak-hak orang lain. Mereka dengan dalih "berdakwah" menggunakan pemaksaan dengan menganggap selain kelompoknya adalah kafir, sesat dan tidak islami, hanya kelompoknya saja yang islami dan sesuai dengan ajaran Rasulullah Muhammad saw. Ada juga gerakan Islam radikal yang menggunakan kekerasan dan perampasan hak-hak orang lain, melakukan teror, dikarenakan orang lain atau kelompok lain yang tak sejalan dengan ajarannya dianggap telah keluar dari Islam dan hukumnya adalah kafir, sehingga harus diperangi, bahkan harta dan jiwanya dihalalkan untuk dirampas. Mereka dengan dalih "berjihad" melawan para kaum kafir yang awalnya adalah bangsa Barat seperti Amerika dan sekutunya mereka musuhi tetapi berkembang sesama umat Islam sendiri atau bangsa sendiri mereka juga

www.nu.or.id/post/read/94817/pendidikan karaktermenjadi-nu-menjadi-indonesia

13 Ibid.

14 Zuly Qodir, "Gerakan Salafi Radikal dalam Konteks Islam Indonesia: Tinjauan Sejarah," Jurnal Islamica, Vol. 3, No. 1, (2008): 10-12. 
perangi dengan dalih membantu kaum kafir.

Dari berbagai kasus radikalisme baik yang terjadi di Indonesia maupun negara lain motivasinya tidaklah tunggal. Terdapat faktor ideologi, politik, ekonomi, hukum, mungkin juga budaya yang menjadi motif. Namun secara umum ada kesamaan yaitu, pertama, terkait literalisme dalam memahami ajaran Islam. Yusuf al-Qaradawi menyebutnya sebagai persoalan kurangnya pemahaman yang benar dan mendalam atas esensi ajaran agama Islam itu sendiri sebagai akibat dari metode literal atas teks-teks agama. ${ }^{15}$ Kedua, persoalan metode dakwah yang mereka gunakan, yang cenderung menggunakan pemaksaaan dan kekerasan dalam menyebarkan pemikirannya. Metode dakwah kekerasan dilakukan dalam aspek doktrin, kultur, dan sosial. Kekerasan secara doktrin berarti mendakwahkan pemikiran Islam literal yang tertutup atas teks-teks keagamaan, dan klaim kebenaran secara tunggal. Kekerasan kultural terkait penggunaan hujatan dan vonis sebagai orang musyrik, murtad, bahkan kafir yang itu juga dilabelkan kepada umat Islam lain. Kekerasan sosial terkait penggunaan aksiaksi anarkis dan destruktif terhadap pihakpihak yang dituduh musyrik, murtad, dan kafir tersebut, sehingga dapat menyebabkan instabilitas dan kegelisahan sosial. ${ }^{16}$ Metode dakwah sangatlah penting untuk keberhasilan dakwah. Pesan yang benar sekalipun jika disampaikan dengan cara yang keliru maka pesan tersebut tidak akan dapat diterima oleh penerima. Apalagi dalam dakwah, tidak hanya pesannya harus benar

15 Yusuf al-Qaradawi, Menuju Pemahaman Islam Yang Kaffah; Analisis Komprehensif tentang Pilar, Karakteristik, Tujuan, dan Sumber-Sumber Acuan Islam, (Jakarta: Insan Cemerlang, 2003), 392. sesuai ajaran Islam yang bisa dipertanggungjawabkan, tetapi juga disampaikan dengan metode dakwah yang bisa dipertanggungjawabkan pula.

Salah satu metode yang dapat dijadikan alternatif untuk membendung dakwah radikalisme adalah metode mujadalah, karena metode tersebut bisa membongkar kesalahan berpikir suatu pemahaman. Kelompok Islam radikal salah satu sebabnya adalah karena keliru memahami dan mengartikan ayat-ayat tentang jihad, keliru dalam memandang penggunaan hukumhukum atau syariat Islam tanpa memandang sejarah, kultur, dan budaya yang ada di Indonesia dengan menyamakan sejarah, kultur, dan budaya Indonesia sama dengan budaya Arab, khususnya pada masa abad keenam Masehi. Tulisan ini memfokuskan pada bagaimana metode dakwah mujadalah untuk membongkar kelemahan-kelemahan dakwah Islam radikal di Indonesia. Metode mujadalah adalah dakwah dengan metode debat atau mempertanyakan kembali ideide atau gagasan yang ada, mengkritisi dengan pendekatan dialektika, logika dasar serta tetap berlandaskan pada hukumhukum Islam yang universal. Jadi fokus studi ini adalah bagaimana menerapkan metode dakwah mujadalah dalam membendung radikalisme Islam di Indonesia. Tujuan dari penelitian ini adalah untuk mendeskripsikan penerapan metode dakwah mujadalah dalam membendung radikalisme Islam di Indonesia. Manfaat studi ini adalah makin memperkaya penerapan metode dakwah yang ada pada metode dakwah Islam. Metodologi yang digunakan adalah metode

\footnotetext{
16 Abdurrahman Wahid (Ed.), Ilusi Negera Islam: Ekspansi Gerakan Islam Transnasional di Indonesia, (Jakarta: The Wahid Institute, 2009), 88-89.
} 
deskriptif kualitatif dengan pendekatan studi pustaka. Data-data dikumpulkan melalui dokumentasi, baik yang berasal dari media atau buku. Adapun kerangka teoretis yang digunakan adalah dialektika dakwah atau dalam bahasa Al-Qur'an disebut dengan metode dakwah mujadalah.

\section{Metode Dakwah Mujadalah}

Metode mujadalah secara bahasa, kata mujadalah terambil dari kata "jadala" yang berarti memintal, menjalin, menganyam dan ketika mengikuti wazan faa'ala maka menjadi jaa dala yang berarti berdebat, berbantah. ${ }^{17}$ Sedangkan secara istilah mujadalah menurut Ali al-Jarisyah dalam upaya tukar pendapat yang dilakukan oleh dua pihak secara sinergis, tanpa adanya suasana yang mengharuskan lahirnya permusuhan di antara keduanya. ${ }^{18}$ Dengan metode dakwah mujadalah maka membongkar kesalahan dalam pola pikir mereka dalam memahami ajaran Islam terutama pada ayat-ayat tentang jihad yang ada dalam Al-Qur'an serta bisa menunjukkan bahwa sebenarnya ajaran Islam adalah ajaran yang membawa kesejukan dan kedamaian serta jauh dari pemaksaan dan perampasan hak-hak individu baik nonmuslim dan lebih-lebih sesama muslim. Dalam menggunakan metode mujadalah tetap berpegangan bahwa objek dakwah yang kita hadapi adalah umat muslim juga yang juga sudah tahu nilai-nilai Islam, bukan umat nonIslam yang belum tahu akan konsep

\footnotetext{
17 A.W. Munawir, Kamus Al Munawir Arab Indonesia Terlengkap, (Surabaya: Pustaka Progressif, 1997), 175.

18 Wahidin Saputra, Pengantar IImu Dakwah, (Jakarta: Raja Grafindo Persada, 2012), 242.

19 Departemen Agama RI, Al-Qur'an dan Terjemahnya dengan Translasi Arab-Latin, (Semarang: Karya Toha Putra Semarang, 1998), 573.
}

ketuhanan, konsep kenabian, dan kitab suci Al-Qur'an, sehingga harus memosisikan jalan dakwah merekalah yang salah bukan konsep keimanan mereka. Beberapa ayat dalam AlQur'an telah membahas tentang metode dakwah mujadalah, di antaranya: "Dan sesungguhnya Kami telah mengulang-ulangi bagi manusia dalam Al-Qur'an ini bermacammacam perumpamaan. Dan manusia adalah makhluk yang paling banyak membantah." 19 (Q.S. Al-Kahfi ayat 54); "Mereka membantahmu tentang kebenaran sesudah nyata (bahwa mereka pasti menang), seolaholah mereka dihalau kepada kematian, sedang mereka melihat (sebab-sebab kematian itu)." ${ }^{20}$ (Q.S. Al-Anfal ayat 6); "Dan janganlah engkau berdebat dengan Ahli Kitab, melainkan dengan cara yang paling baik, kecuali dengan orang-orang yang zalim di antara mereka, dan katakanlah: "kami telah beriman kepada (kitab-kitab) yang telah diturunkan kepada kami dan yang diturunkan kepadamu; Tuhan kami dan Tuhan kamu adalah satu; dan kami hanya kepada-Nya berserah diri." ${ }^{21}$ (Q.S. AlAnkabut ayat 46); "Serulah (manusia) kepada jalan Tuhanmu dengan hikmah dan pelajaran yang baik dan bantahlah mereka dengan cara yang baik..." (Q.S. An-Nahl ayat 125). ${ }^{22}$

Metode mujadalah adalah metode debat dengan proses dialektika, ${ }^{23}$ di mana metode ini berfungsi untuk membongkar doktrindoktrin yang sudah ditanamkan dalam otak para mad'uw pengikut Islam radikal. Sasaran dari teknik ini adalah rasional dan perasaan

\footnotetext{
20 lbid., 338.

21 lbid., 793.

22 Ibid., 536.

23 Cecep Sumarna, Filsafat Pengetahuan, (Bandung: Rosda Karya 2006), 132.
} 
dari objek dakwah, metode ini pernah digunakan oleh para nabi dalam menjalankan misi dakwahnya, seperti debatnya Nabi Ibrahim dengan Raja Namruz tentang siapa sebenarnya yang menjadi Tuhan Yang Mahakuasa yang bisa mematikan dan menghidupkan makhluk hidup. Perdebatan tersebut didokumentasikan dalam Q.S. Al-Baqarah :258 "Apakah kamu tidak memperhatikan orang yang mendebat Ibrahim tentang Tuhannya (Allah), karena Allah telah memberikan kepada orang itu pemerintahan (kekuasaan). Ketika Ibrahim mengatakan: 'Tuhanku ialah Yang menghidupkan dan mematikan,' orang itu berkata: 'Saya dapat menghidupkan dan mematikan.' Ibrahim berkata: 'Sesungguhnya Allah menerbitkan matahari dari timur, maka terbitkanlah ia dari barat,' lalu heran terdiamlah orang kafir itu; dan Allah tidak memberi petunjuk kepada orang-orang yang zalim." ${ }^{24}$

Juga peristiwa perdebatan antara $\mathrm{Nabi}$ Ibrahim dengan para penyembah berhala. $\mathrm{Di}$ mana Nabi Ibrahim menghancurkan seluruh berhala-berhala kecil dan menaruh kapak yang digunakan untuk menghancurkan berhala tersebut pada berhala yang paling besar, sambil berkata "Sebenarnya (patung) yang besar itu yang melakukannya, maka tanyakanlah kepada mereka, jika mereka dapat berbicara." 25 Selanjutnya jawaban orang-orang kafir tersebut pada $\mathrm{Nabi}$ Ibrahim, "Maka mereka kembali kepada kesadaran mereka dan berkata, "Sesungguhnya kamulah yang menzalimi (diri sendiri), kemudian mereka jadi menundukkan kepala (lalu berkata), "Engkau

\footnotetext{
24 Departemen Agama RI, Al-Qur'an dan Terjemahnya dengan Translasi Arab-Latin, 79-80.

25 Ibid., 634.
}

(Ibrahim) pasti tahu bahwa (berhalaberhala) itu tidak dapat berbicara." 26

Dalam Al-Qur'an juga dikisahkan peristiwa perdebatan antara Nabi Musa dengan Firaun tentang menghidupkan dan mematikan manusia, "Dia (Fir'aun) berkata, "Siapakah Tuhanmu berdua, wahai Musa? Dia (Musa) menjawab, "Tuhan kami ialah (Tuhan) yang telah memberikan bentuk kejadian kepada segala sesuatu, kemudian memberinya petunjuk." Dia (Fir'aun) berkata, "Jadi bagaimana keadaan umat-umat yang dahulu?" Dia (Musa) menjawab, "Pengetahuan tentang itu ada pada Tuhanku, di dalam sebuah kitab (Lauh Mahfuz), Tuhanku tidak akan salah ataupun lupa; (Tuhan) yang telah menjadikan bumi sebagai hamparan bagimu, dan menjadikan jalan-ja]an di atasnya bagimu, dan yang menurunkan air (hujan) dari langit. Kemudian Kami tumbuhkan dengannya (air hujan itu) berjenis-jenis aneka macam tumbuh-tumbuhan. Makanlah dan gembalakanlah hewan-hewanmu. Sungguh, pada yang demikian itu, terdapat tandatanda (kebesaran Allah) bagi orang yang berakal. ${ }^{27}$ Juga diceritakan dialog perdebatan antara Nabi Muhammad dengan pendeta Nasrani dari Najran tentang Isa putra Maryam yang didokumentasikan dalam Al-Qur'an. ${ }^{28}$

Dari ketiga kisah yang diabadikan dalam AlQur'an menunjukkan metode dakwah mujadalah cara bekerjanya dengan membongkar paradigma berpikir yang keliru, dengan pendekatan logika-logika berpikir. Dalam penyampaian argumenargumennya, Al-Qur'an menggunakan

\footnotetext{
${ }^{26} \mathrm{Ibid}$.

27 Ibid., 607.

28 Ibid., 105-106.
} 
beberapa metode di antaranya pertama, menggunakan kata tanya penetapan. Maksud dari kata tanya ini adalah menjadikan lawan bicara mengakui dan menyatakan dengan pasti akan adanya sesuatu atau tidak adanya sesuatu tersebut, seperti "Dan bukankah (Allah) yang menciptakan langit dan bumi, mampu menciptakan kembali yang serupa itu (jasad mereka yang sudah hancur itu)? Benar, dan Dia Maha Pencipta, Maha Mengetahui."29 Kata tanya tersebut penting untuk pembuka debat karena untuk menunjukkan kepastian persoalan yang mau diperdebatkan.

Kedua, analogi asosiasi atau qiyas, yang dimaksud dengan qiyas adalah penyamaan sesuatu dengan sesuatu yang lain. Proses penyamaan itu dilakukan dengan menyamakan sesuatu dengan sesuatu yang lain yang sama-sama diakui oleh lawan bicara, seperti "Sesungguhnya perumpamaan (penciptaan) Isa bagi Allah, seperti (penciptaan) Adam. Dia menciptakannya dari tanah, kemudian Dia berkata kepadanya, "Jadilah!" Maka jadilah sesuatu itu"30 Ayat tersebut untuk membantah pendeta Nasrani yang menganggap bahwa Isa adalah anak Tuhan yang dilahirkan tanpa ayah hanya ibu saja. Al-Qu'ran menunjukkan justru Nabi Adam lahir tanpa ayah dan ibu. Maka dengan Nabi Muhammad menunjukkan hukum-hukum yang ada dalam Al-Qur'an tersebut maka pendeta Nasrani tidak bisa membantahnya.

Ketiga, teori penukaran dalil, yang dimaksud dengan teori ini adalah penukaran dalil dengan dalil lain yang sepadan atau dari satu

\footnotetext{
${ }^{29}$ Ibid., 883.

30 Ibid., 105.
}

contoh ke contoh yang lain. Hal itu dikarenakan lawan bicara tidak paham dengan dalil atau contoh yang pertama, atau ia hanya berpura-pura tidak paham dengan maksud membuat pengaburan atau memutarbalikkan fakta. Teori penukaran dalil ini telah dibuktikan Nabi Ibrahim ketika menghadapi Raja Namruz yang mendebatnya. Kisah perdebatannya telah diabadikan Allah dalam Al-Qur'an. Namruz dengan kekuasaannya bisa mengampuni dan menghukum mati seseorang maka dia mengatakan bahwa dia bisa menghidupkan dan mematikan, tetapi dengan argumentasi Ibrahim bahwa Allah bisa menerbitkan matahari dari barat dan menantang Namruz menerbitkannya dari timur maka dia terdiam.

Jadi metode mujadalah ini adalah metode komunikasi dakwah yang efektif untuk membongkar pemahaman Islam radikal yang keliru. Metode ini relevan dan realistis sesuai dengan tantangan dan kebutuhan, dengan memikirkan kadar kemampuan akal dan suasana psikologis serta sosio-kultural mad'uw. $^{31}$

Metode dakwah mujadalah adalah dengan cara melakukan perdebatan dengan menggunakan pendasaran-pendasaran logika, tetapi dalam menggunakan mujadalah tersebut tetap ada prinsip-prinsip komunikasi dakwah yang sudah diatur dalam Al-Qur'an. Ada beberapa prinsip dalam AlQur'an yang dapat digunakan dalam setiap aktivitas dakwah melalui dakwah mujadalah ini yaitu, ${ }^{32}$ pertama, prinsip qaulan syadidan “...Hendaklah mereka bertakwa kepada

\footnotetext{
31 Muhyidin, Asep, Dakwah Dalam Perspektif AlQur'an, (Bandung: Pustaka Setia 2002),164.

${ }^{32}$ Syamhudi, M. Hasyim, Filsafat Dakwah, (Yogyakarta: Pustaka Ilmu, 2014), 47.
} 
Allah dan hendaklah mereka mengucapkan perkataan yang benar" ${ }^{\prime 33}$ yaitu sesuai dengan fakta yang didukung data. Dalam prinsip qoulan syadidan dakwah dengan metode mujadalah memberikan data-data kebenaran yang sesuai dengan fakta, tidak melakukan manipulasi data atau menyembunyikan fakta dan data-data. Kedua, prinsip qaulan balighan, "Katakanlah kepada mereka perkataan yang membekas pada jiwa mereka," ${ }^{34}$ karena apa yang disampaikan bertemu dalam satu medan pengalaman, field experience antara mad'uw dan dai. Kalau dalam qaulan sadida banyak menguji tentang data dan fakta di mana penekanan metode ini adalah argumentasi data-data yang logis atau menyentuh pada tataran kognisi lawan bicara, tetapi untuk metode qaulan balighan perkataanperkataan kita tentang fakta dan data tersebut harus disertai penekananpenekanan terutama pada persoalanpersoalan yang berbeda, dengan adanya intonasi, diksi, dan tempo yang kita atur saat debat maka secara psikologis lawan bicara akan terpengaruh, dalam artian bisa menyentuh afeksi lawan bicara.

Ketiga, prinsip qaulan maysuro, “...maka katakanlah kepada mereka ucapan yang pantas". ${ }^{35}$ Fungsi prinsip qaulan maysuro dalam metode mujadalah adalah, supaya saat proses debat membahas suatu tema tidak melebar ke tema-tema yang selainnya dan tidak mendiskreditkan lawan debat dengan cara merendahkan atau mengungkit kekurangan fisik atau sejarah yang jelek dari lawan bicara, padahal tema debat yang dibahas bukan itu. Sehingga saat kita fokus

33 Departemen Agama RI, Al-Qur'an dan Terjemahnya dengan Translasi Arab-Latin, 79-80.

34 Ibid., 163.

35 Ibid., 543. membahas masalah dan tidak membahas kejelekan lawan bicara, mereka akan bisa menerima kebenaran meski dari pihak di luar dirinya, dan tidak tertutupi oleh dendam dan iri hati. Keempat, prinsip qaulan layyinan. "Maka berbicaralah kamu berdua kepadanya dengan kata-kata yang lemah lembut, mudah-mudahan ia ingat atau takut". ${ }^{36}$ Dengan perkataan qaulan layyinan maka lawan debat tidak merasa dibuat malu atau harga dirinya direndahkan apalagi kalau debat dilakukan di depan publik yang banyak dilihat orang, maka lawan debat akan resistan terhadap kebenaran yang dibawa lawan bicaranya, apalagi jika penyampaiannya kasar dan mendiskreditkannya, meskipun yang disampaikan data-data kebenaran. Kelima, prinsip qaulan kariman. Dan ucapkanlah kepada mereka (kedua orang tua) dengan perkataan mulia (pilihan kata yang tidak menghinakan dan tidak mematikan karakter mad'uw). ${ }^{37}$ Secara prinsip qaulan karima dengan qaulan layyinan adalah sama yaitu menghargai lawan debat kita, dan memosisikan bahwa mereka adalah saudara sesama muslim, dan tujuan berdebat adalah untuk mencari kebenaran bukan menambah lawan. Keenam, prinsip qaulan ma'rufan. Dan ucapkanlah kepada mereka kata-kata yang baik (penggunaan kata-kata yang tidak jorok, membosankan serta mempertimbangkan aspek moralitas. ${ }^{38}$ Prinsip qaulan ma'rufan adalah penggunaan kata-kata yang baik, pemilihan diksi yang tepat dan tidak menggunakan kata-kata kotor, kasar, bahkan mengumpat lawan bicaranya, sehingga membuat lawan bicara tersinggung atau juga audiens yang melihat

\footnotetext{
${ }^{36}$ Ibid., 606.

${ }^{37}$ Ibid., 542.

38 Ibid., 142-143.
} 
debat tersebut juga menjadi tidak simpatik. Meskipun yang disampaikan kebenaran tapi kalau pemilihan-pemilihan diksi salah maka kebenaran yang dibawa juga sulit untuk diterima.

Pesan dakwah yang terangkum dalam visi dakwah dan disampaikan melalui formulasi misi mujadalah yang tidak berdiri sendiri tetapi berada di atas landasan misi hikmah jelas akan menciptakan suasana harmonis dan sejuk dan ini akan memudahkan diterimanya pesan-pesan dakwah sebagai landasan pengondisian rahmatan li alalamin dalam tataran kehidupan sehari-hari serta keselamatan di akhirat. ${ }^{39}$

\section{Dakwah Kelompok Islam Radikal di Indonesia}

\section{Sejarah Islam Radikal di Indonesia}

Radikalisme agama yang dilakukan oleh gerakan Islam garis keras dapat ditelusuri lebih jauh ke belakang. Gerakan ini telah muncul pada masa kemerdekaan Indonesia, bahkan dapat dikatakan sebagai akar gerakan Islam garis keras era reformasi. Gerakan dimaksud adalah DI/TII (Darul Islam/Tentara Islam Indonesia) dan Negara Islam Indonesia (NII) yang muncul era 1950an (tepatnya 1949). Darul Islam atau NII mulanya di Jawa Barat, Aceh, dan Makassar. Gerakan ini disatukan oleh visi dan misi untuk menjadikan syariat sebagai dasar negara Indonesia. Gerakan DI/TII adalah gerakan berbagai kepentingan yang menjadi satu, antara kepentingan penegakan syariat Islam dan juga kekecewaan kepada pemerintahan Soekarno karena dianggap

\footnotetext{
${ }^{39}$ Syamhudi. Filsafat Dakwah. 49.

${ }^{40}$ Muhammad Reno, ISIS: Kebiadaban Konspirasi

Global, (Bandung: Penerbit Noura Books, 2014), 80-82
}

tidak adil dan sentralisistis dalam pembagian kekuasaan, seperti DI/TII di Jawa Barat dan Jawa Tengah yang dipimpin oleh Kartosoewiryo dan Ibnu Hajar mereka menuntut penegakan negara Islam Indonesia. DI/TII Aceh di bawah komando Teungku Daud Beureueh mereka menuntut janji Soekarno akan pemberlakukan syariat Islam di daerah Aceh. Sedangkan DI/TII Sulawesi Selatan yang dipimpin oleh Kahar Muzakkar menuntut pemerataan pembagian kekuasaan di daerah Sulawesi salah satunya adalah pengakuan pasukan perang. Gerakan DI/TII ini berhenti setelah semua pimpinannya terbunuh pada awal 1960-an. Sungguhpun demikian, bukan berarti gerakan semacam ini lenyap dari Indonesia. Pada awal tahun 1970-an dan 1980-an gerakan Islam garis keras muncul kembali, seperti Komando Jihad, pembajakan pesawat Garuda oleh kelompok Imron, kasus Talangsari oleh Warsidi dan Teror Warman di Lampung untuk mendirikan negara Islam, dan semacamnya, semua kasus-kasus tersebut selalu terhubung kepada NII dan sempalansempalannya. ${ }^{40}$

Pada awalnya, alasan utama dari radikalisme agama atau gerakan-gerakan Islam garis keras tersebut adalah dilatarbelakangi oleh politik lokal seperti ketidakpuasan politik, keterpinggiran politik, dan semacamnya. Namun setelah terbentuknya gerakan tersebut, agama meskipun pada awalnya bukan sebagai pemicunya, kemudian menjadi faktor legitimasi maupun perekat yang sangat penting bagi gerakan Islam garis keras. Sungguhpun begitu, radikalisme agama yang dilakukan oleh sekelompok 
muslim tidak dapat dijadikan alasan untuk menjadikan Islam sebagai sumber radikalisme.

Radikalisme berpotensi menjadi bahaya besar bagi masa depan peradaban manusia. Gerakan radikalisme ini awalnya muncul sebagai bentuk perlawanan terhadap komunisme di Indonesia. Selain itu, perlawanan mereka terhadap penerapan Pancasila sebagai asas tunggal dalam politik. Bagi kaum radikalis agama sistem demokrasi pancasila itu dianggap haram hukumnya dan pemerintah di dalamnya adalah kafir tagut, begitu pula masyarakat sipil yang bukan termasuk golongan mereka. Oleh sebab itu, bersama kelompoknya kaum ini menggaungkan formalisasi syariat sebagai solusi dalam kehidupan bernegara. ${ }^{41}$

Selain gerakan radikalisme Islam yang memang berakar dari sejarah perjuangan umat Islam di Indonesia. Pada tahun 1980-an sampai dengan tahun 1990-an muncul gerakan-gerakan Islam yang berasal dari Timur Tengah, seperti Mesir, Yaman, dan Iran, gerakan-gerakan Islam ini dikenal dengan gerakan Islam transnasionalisme. Gerakan ini didominasi oleh corak pemikiran normatif, skripturalis, dan fundamentalis yang terkadang secara parsial mengadaptasi gagasan dan instrumen modern. Beberapa organisasi Islam yang termasuk dalam kategori gerakan Islam transnasional dan kaki tangannya yang ada di Indonesia antara lain: Ikhwanul Muslimin di Mesir, Hizbut Tahrir di Lebanon, Wahabiyah di Arab Saudi, Jama'ah Islamiyah di Pakistan, Gerakan Salafi Jihadis di Irak dan Afganistan, serta Syiah yang berpusat di Iran. Gerakan Islam transnasional telah membawa pengaruh

41 Ibid., 85

42 Ibid., 64. yang cukup kuat di Indonesia sampai saat ini. Apalagi keberhasilan beberapa pergerakan umat Islam dalam melawan rezim penguasa dianggap sebagai masa keemasan Islam yang muncul kembali, jatuhnya rezim Syah Pahlevi oleh gerakan rakyat Iran yang dimotori oleh Imam Khomeini pada tahun 1979 membawa awal perubahan perlawanan umat Islam di dunia dan terus berlanjut pada perlawanan pejuang Afganistan yang melawan Soviet, perjuangan umat Islam di Bosnia, Khasmir, Palestina, dan Moro menjadi motivasi tersendiri bagi munculnya gerakan radikalisme Islam di Indonesia. ${ }^{42}$

\section{Karakteristik Islam Radikal dalam}

\section{Berdakwah}

Istilah radikalisme berasal dari bahasa Latin "radix" yang artinya akar, pangkal, bagian bawah, atau bisa juga berarti menyeluruh, habis-habisan dan amat keras untuk menuntut perubahan. Menurut KBBI radikalisme berarti: (1) paham atau aliran yang radikal dalam politik; (2) paham atau aliran yang menginginkan perubahan atau pembaharuan sosial dan politik dengan cara kekerasan atau drastis; (3) sikap ekstrem dalam aliran politik. ${ }^{43}$ Pengertian lain mengungkapkan bahwa yang dimaksud dengan radikal atau radikalisme itu adalah prinsip-prinsip atau praktik-praktik yang dilakukan secara radikal. Suatu pilihan tindakan yang umumnya dilihat dengan mempertentangkan secara tajam antara nilai-nilai yang diperjuangkan oleh kelompok (aliran) agama tertentu dengan tatanan nilai yang berlaku atau dipandang mapan pada

\footnotetext{
${ }^{43}$ Tim Departemen Pendidikan Nasional, Kamus Besar Bahasa Indonesia,(Jakarta: Balai Pustaka, 2008), 1151
} 
saat itu. ${ }^{44}$ Istilah radikalisme Islam menunjuk pada munculnya berbagai gerakan Islam yang menggunakan berbagai bentuk kekerasan dalam rangka perjuangan untuk mendirikan "Negara Islam." ${ }^{45}$ Kesan karakter gerakan yang keras tersebut bisa terlihat dari nama dan terminologi yang mereka gunakan sebagai nama kelompok mereka yang berkonotasi kekerasan dan militeristik, seperti laskar, tentara (jundul), hizbul (partai), front pembela, dan sebagainya. ${ }^{46}$

Martin E. Marty and R. Scott Appelby, memberikan ciri-ciri kelompok radikal sebagai berikut: (1) menentang modernisme termasuk di dalamnya otonomi individual, hegemoni nalar dan ideologi kemajuan, termasuk di dalamya paham empirisme, scientism dan meritokrasi. Kaum fundamentalis tidak punya kepentingan dengan demokrasi, pluralisme, toleransi agama, kebebasan berbicara, dan lain-lain. Namun mereka, sungguhpun antisekulerisme, namun tetap menjadi pengguna alat-alat hasil teknologi seperti komputer, internet, pesawat, alat-alat perang modern, dan lain-lain; (2) meyakini bahwa kitab suci itu tidak bisa dan tidak akan pernah salah termasuk penafsiran mereka sendiri akan teks-teks suci itu. Dengan kata lain mereka hanya menerima penafsiran kelompoknya sajalah yang benar sementara yang lain salah; (3) hanya meyakini kelompoknya saja yang benar dan selamat; (4) cenderung bersikap tertutup alias eksklusif terhadap kelompok lain, namun

44 Kementerian Agama Republik Indonesia, Radikalisme Agama dan Tantangan Kebangsaan, (Jakarta: Direktorat Jenderal Bimbingan Masyarakat Islam Kemenag RI, 2014), 3.

45 M. Imdadun Rahmat. Arus Baru Islam Radikal: Transmisi Revivalisme Islam Timur Tengah ke Indonesia, (Jakarta: Erlangga 2005), 153.

46 Ibid. sangat kuat ikatan persaudaraan sesama anggota; (5) kaum fundamentalis cenderung bersikap reaktif, defensif, dan selektif serta tak segan-segan menggunakan jalan kekerasan untuk merealisasikan tujuannya. ${ }^{47}$

Sedangkan pengertian Islam radikal adalah orang Islam yang mempunyai pikiran yang kaku dan sempit dalam memahami Islam, serta bersifat eksklusif dalam memandang agama-agama lainnya. Kelompok radikal ini akan ada di dalam setiap agama apapun, termasuk di dalam agama Islam sekalipun. ${ }^{48}$ Biasanya dalam kelompok Islam dinamakan "Harakah" sehingga gerakan Islam dikenal dengan "al Harakah al Islamiyah," lebihlebih dalam gerakan Islam yang berkarakter ideologis. Dalam gerakannya Islam radikal mempunyai beberapa karakteristik sebagai berikut: (1) isu utama yang diangkat adalah penegakan syariat Islam (tathbiq al-Syari'at) dengan tujuan formalisasi penerapan syariat Islam dalam kehidupan bernegara dan bermasyarakat; ${ }^{49}$ (2) penegakan Islam kafah, dalam artian mengajak kembali pada ajaran dan praktik Islam seperti yang dicontohkan oleh Nabi Mumammad dan diikuti oleh sahabatnya selanjutnya diteruskan oleh para tabiin dan juga para tabiin-tabiin, yang secara umum dianggap sebagai praktik salaf saleh; (3) mengembangkan paham pembentukan kepemimpinan Islam baik imamah maupun kekhilafahan Islam sebagai konsep tunggal/monolitik dengan merujuk

\footnotetext{
${ }^{47}$ Anzar Abdullah, "Gerakan Radikalisme Dalam Islam: Perspektif Historis," ADDIN, Vol. 10 No. 1 (2016).

48 Said Aqil, "Bibit Radikalisme Telah Ada Sejak Zaman Rasulullah," NU Online, diakses 12 Desember 2019. www.nu.or.id/post/read/37266/said-aqil-bibitradikalisme-telah-ada-sejak-zaman-rasulullah ${ }^{49}$ Khamami, Zada, Islam Radikal: Pergulatan Ormasormas Islam Garis Keras di Indonesia, (Jakarta:Penerbit Teraju, 2002), 133.
} 
pada masa Nabi dan khulafaurasyidin; ${ }^{50}$ (4) bercita-cita memperjuangkan berdirinya negara Islam ataukah khilafah Islamiah, dengan syariat Islam sebagai praktik hukum di masyarakat; ${ }^{51}$ (5) membagi wilayahwilayah ke dalam tiga kategori, Dar al salam atau negara Islam dan Dar al harb atau negara konflik/perang, serta mewajibkan umat Islam menjalankan syariat Islam secara menyeluruh, dan untuk Dar al Salam penduduknya dikenakan pajak, tetapi kalau Dar al Harb dikenakan fa'i dan apabila melawan, harta bendanya bisa dirampas (ganimah); (6) menentang berbagai bentuk sistem dan ideologi dari luar Islam, seperti halnya sistem sekuler, liberal, barat, dan yang dikategorikan sebagai anti-Islam serta menjadikan jihad sebagai konsep perang adalah pilar yang penting dalam perjuangan menegakkan syariat Islam. ${ }^{52}$

Selain itu gerakan Islam radikal juga terjadi dalam bentuk perlawanan terhadap Barat.

Reaksi yang ditunjukkan berupa perlawanan dengan kekerasan terhadap kepentingan atau perusahaan multinasional Barat. Kantor kedutaan dan perusahan Amerika Serikat (AS) sering menjadi sasaran kekerasan yang diilhami oleh pemahaman kaum radikal sebagai perjuangan agama. Selain itu juga seruan boikot terhadap produk-produk Barat terutama Amerika, dengan memberi label produk-produk tersebut haram dan keuntungan dari produk tersebut digunakan untuk pembiayaan programprogram penindasan terhadap umat Islam. Maka jihad menjadi simbol perlawanan

50 Haedar Nashir, Islam Syariat: Reproduksi Salafiyah Ideologis di Indonesia, (Bandung: Mizan, ,2013),108.

51 Jamhari Jajang Jahroni, Gerakan Salafi Radikal di Indonesia, (Jakarta: Raja Grafindo Persada, 2004),185.

${ }^{52}$ Nashir, Islam Syariat: Reproduksi Salafiyah Ideologis di Indonesia, 109. efektif untuk menggerakkan perang melawan Barat. Kondisi ini menyebabkan permusuhan yang berlanjut antara Islam dan Barat. Bahkan, kalangan Islam radikal melihat Barat berada dalam pertarungan abadi melawan Islam.

Karakteristik kelompok Islam radikal adalah penekanan pada Islam simbol daripada Islam substansi. Pertentangan perlunya simbolsimbol Islam yang harus dilegalkan bahkan dijadikan sebagai peraturan sebenarnya sudah lama terjadi pada umat Islam di Indonesia. ${ }^{53}$ Peristiwa penegakan syariat Islam lewat pemberlakuan Piagam Jakarta yang telah dihasilkan oleh Badan Penyelidik Usaha-usaha Persiapan Kemerdekaan Indonesia (BPUPKI), pada tanggal 18 Agustus 1945 sehari setelah Indonesia merdeka dibatalkan oleh Panitia Persiapan Kemerdekaan Indonesia (PPKI), dimana beberapa pasal yang ada pada Piagam Jakarta dihapus dan ada yang diganti baru, di antaranya: (1) pada sila pertama Pancasila yang tertulis dalam Piagam Jakarta adalah Ketuhanan dengan Kewajiban Menjalankan Syariat Islam bagi Pemeluknya, maka diputuskan untuk menghapus tujuh kata "Dengan Kewajiban Menjalankan Syariat Islam Bagi Pemeluknya, " dan diganti dengan Ketuhanan Yang Maha Esa; ${ }^{54}$ (2) istilah Muqaddimah dalam Undang-Undang Dasar 45 diubah menjadi Pembukaan Undang-Undang Dasar 45, karena dianggap kata mukadimah adalah kata Arab bukan Bahasa Indonesia; (3) kemudian mencoret kalimat "beragama Islam" dalam Pasal 6 ayat 1 UUD 1945 dari semula berbunyi: “Presiden

\footnotetext{
53 Endang Saifudin Anshari, Piagam Jakarta 22 Juni 1945. (Bandung: Gema Insani Press, 1997), 52.

54 Yudi Latif, Inteligensia Muslim dan Kuasa, (Jakarta: Democracy Project, Yayasan Abad Demokrasi Indonesia, 2012), 94.
} 
ialah orang Indonesia asli dan beragama Islam" menjadi "Presiden ialah orang Indonesia asli.."

Gagalnya Piagam Jakarta adalah peristiwa gagalnya perjuangan umat Islam dalam memasukkan syariat Islam pada peraturan perundang-undangan di Indonesia dimaknai gagalnya perjuangan umat Islam sehingga memunculkan reaksi. Bagi kelompok Islam garis keras atau Islam radikal, maka memunculkan bahwa harus ada perlawanan dengan membentuk negara tandingan dan dimunculkanlah Negara Islam Indonesia atau NII yang dipimpin oleh Kartosoewirjo. Peristiwa itu adalah awal bahwa ajaran Islam harus ditegakkan lewat simbol-simbol kenegaraan atau perundang-undangan. Saat masa orde baru di awal tahun 90-an juga muncul perlunya ekonomi Islam yang mandiri dan terbebas dari riba, umat Islam menuntut adanya regulasi sendiri yang mengatur tentang perbankan yang berdasarkan syariah. ${ }^{56}$ Akhirnya pemerintah merespon dengan memunculkan bank Muamalat dan Bank Perkreditan Rakyat Syariah (BPR Syariah) serta berlanjut pada bank-bank konvensional yang juga mendirikan bank syariah. Saat masa orde reformasi muncul tuntutan perda-perda syariat Islam dan juga daerah otonomi khusus yang menjalankan syariat Islam. ${ }^{57}$ Dari paparan di atas menunjukkan bahwa meskipun Piagam Jakarta dianggap gagal tetapi harus tetap ada perjuangan umat

\footnotetext{
${ }^{55}$ Ahmad Syafii Ma'rif, Islam dan Politik: Teori Belah Bambu, Masa Demokrasi Terpimpin (1959-1965). (Jakarta: Gema Insani Press, 1996), 112.

56 Budi Darmawan, "Sejarah Berdirinya Muamalat, Bank Syariah Pertama di Indonesia," EkonomiIslam.com, diakses 29 Oktober 2018 https://ekonomiislam.com/sejarah-berdirinya-muamalat-banksyariah-pertama-di-indonesia/
}

Islam yang diwujudkan dalam simbol-simbol Islam dan perda-perda yang mengatur tentang hukum Islam. Sehingga minimal jika dalam Undang-Undang gagal, harus dapat dimunculkan pada level yang lebih kecil lagi yaitu daerah, maka desakan perda-perda syariat Islam masih perlu untuk ditegakkan.

\section{Metode Dakwah Islam Radikal}

Dalam pengembangan metode dakwahnya, kelompok Islam radikal tidak jarang melakukan rasionalisasi metode dakwah. Istilah rasionalisasi adalah mekanisme pertahanan yang dianggap sebagai perilaku yang kontroversial atau perasaan yang dijelaskan secara rasional atau logis untuk menghindari penjelasan yang benar. $^{58}$ Sehingga yang dimaksud dalam rasionalisasi metode dakwah adalah mencari alasan pembenaran dari metode yang dilakukannya, semisal kelompok N11, mereka membagi wilayah Indonesia sama seperti zaman Nabi ada darul Islam dan darul harb, sehingga hukum yang berlaku adalah hukum Makkah dan hukum Madinah, atau seperti HTI yang menganggap cara dakwah mereka sama dengan cara Nabi dan menyamakan kondisi masyarakat saat ini juga sama dengan masyarakat pra-Nabi Muhammad SAW, bahwa Nabi berhasil menguasai darul kufur, dengan merombak sistemnya mengganti dengan darul Islam, dan puncaknya adalah berdirinya negara Madinah. ${ }^{59}$ Padahal keberhasilan sebuah metode itu juga disesuaikan dengan kondisi

\footnotetext{
57 Taufiq Siddiq, "Daerah dengan Perda Syariah dan Injil dari Aceh hingga Papua," Tempo.co, diakses 10 Februari 2020

https://nasional.tempo.co/read/1147430/daerahdengan-perda-syariah-dan-injil-dari-aceh-hinggapapua

58 Brian P. McLaughlin and Amelie Rorty, Perspectives on self-deception, (London: University of California Press, 1988), 45.

${ }^{59}$ Nashir, 104.
} 
real mad'uw. Apabila memaksakan metode tanpa melihat konteks dari mad'uw dan sosio-kultur yang ada, maka hanya akan menjumpai kegagalan dalam berdakwah.

Metode pada dasarnya adalah sebuah cara, sedangkan pengertian metode secara istilah metode adalah jalan yang dilalui untuk mencapai tujuan. Untuk mencapai tujuannya Islam radikal mempunyai metode dakwah sendiri, yang di luar dari kebiasaan metode dakwah yang diterapkan para dai pada umumnya. Dalam teori dakwah definisi dari metode dakwah adalah cara-cara tertentu yang dilakukan oleh seseorang dai (komunikator) kepada mad'uw yang mencapai suatu tujuan atas dasar hikmah dan kasih sayang. Hal ini mengandung arti bahwa pendekatan dakwah harus bertumpu pada suatu pandangan human oriented menempatkan penghargaan yang mulia atas diri manusia. ${ }^{60}$ Sedangkan bagi kelompok Islam radikal metode dakwah yang diterapkan pada mad'uw, baik yang sifatnya individu/dakwah fardiyah atau ke masyarakat/dakwah ummah, secara umum mereka menggunakan cara indoktrinasi dan provokasi.

Pertama, indoktrinasi. Indoktrinasi adalah sebuah proses yang dilakukan berdasarkan satu sistem nilai untuk menanamkan gagasan, sikap, sistem berpikir, perilaku, dan kepercayaan tertentu. Dengan cara ini mereka mencoba mendoktrin bahwa pemahaman masyarakat tentang Islam selama ini adalah keliru, dengan menggunakan dalil-dalil ayat Al-Qur'an, terutama ayat-ayat tentang jihad seperti

${ }^{60}$ Abdul Munir Mulkhan dan Bilveer Singh, Demokrasi di Bawah Bayangan Mimpi N-11: Dilema Politik Islam dalam Peradaban, (Jakarta:Kompas, 2011), 109.

${ }^{61}$ Departemen Agama RI, Al-Qur'an dan Terjemahnya dengan Translasi Arab-Latin, 56. pada surah Al-Baqarah ayat 190 "Dan perangilah di jalan Allah orang-orang yang memerangi kamu ..." 61 kemudian tentang perang pada surah Al-Hajj ayat 39 "Telah diizinkan (berperang) bagi orang-orang yang diperangi ..." ${ }^{62}$ dan tentang perilaku orangorang kafir dan nonmuslim pada surah AlBaqarah ayat 120 "Orang-orang Yahudi dan Nasrani tidak akan senang kepada kamu hingga kamu mengikuti agama mereka ..." ${ }^{63}$ semisal doktrin amar makruf nahi mungkar ini tidak dipakai oleh kaum muslim untuk membenarkan perilaku intoleran dan bahkan tindak kekerasan kepada orang lain. Firman Allah dalam surah Ali Imran ayat 104 menyebutkan "Dan hendaklah ada di antara kamu segolongan umat yang menyeru kepada kebajikan, menyuruh kepada yang makruf dan mencegah dari yang mungkar; merekalah orang-orang yang beruntung." ${ }^{64}$

Semua ayat-ayat Al-Qur'an yang bermakna jihad, dimaknai tunggal oleh kelompok mereka yaitu jihad fisik atau perang, seperti kelompok Negara Islam Indonesia atau dikenal NII atau N11, mereka berpemahaman bahwa ada tiga daerah dalam Indonesia, yaitu (a) darul kufur, daerah di mana ditempati oleh pemerintahan yang batil, bagi mereka saat zaman orde lama, Presiden Soekarno dianggap kafir dan tagut maka daerah kekuasaannya merupakan darul kufur; (b) darul harb, daerah ini adalah daerah perang di mana sering terjadi konflik perang di daerah tersebut, antara tantara DI/TII dengan TNI atau rakyat yang mendukung Presiden Soekarno; (c) darul Islam, daerah ini adalah daerah kekuasaan Kartosoewirjo

\footnotetext{
62 Ibid., 654.

63 Ibid., 36.

64 Ibid., 116
} 
bersama $\mathrm{DI} / \mathrm{TII}$ maka di daerah ini yang berlaku adalah hukum Islam atau qanun asasi, bukan hukum yang berlaku di Indonesia.

Selain ayat-ayat jihad, mereka juga memaknai ayat-ayat hukum, semisal hukuman bagi pezina dalam surah An-Nur ayat 2 "Perempuan yang berzina dan laki-laki yang berzina, maka deralah tiap-tiap seorang dari keduanya seratus kali dera, dan janganlah belas kasihan kepada keduanya mencegah kamu untuk (menjalankan) agama Allah, jika kamu beriman kepada Allah, dan hari akhirat, dan hendaklah (pelaksanaan) hukuman mereka disaksikan oleh sekumpulan dari orang-orang yang beriman" 65 atau hukuman bagi pelaku pencurian dalam surah Al-Maidah ayat 38, "Laki-laki yang mencuri dan perempuan yang mencuri, potonglah tangan keduanya (sebagai) pembalasan bagi apa yang mereka kerjakan dan sebagai siksaan dari Allah. Dan Allah Mahaperkasa lagi Mahabijaksana." ${ }^{66}$ Juga ayat yang mengatur tentang hukuman bagi manusia yang melakukan perampasan hak (perampokan) dalam surah Al-Maidah ayat 33, "Sesungguhnya pembalasan terhadap orang-orang yang memerangi Allah dan Rasul-Nya dan membuat kerusakan di muka bumi, hanyalah mereka dibunuh atau disalib, atau dipotong tangan dan kaki mereka dengan bertimbal balik, atau dibuang dari negeri (tempat kediamannya). Yang demikian itu (sebagai) suatu penghinaan untuk mereka di dunia, dan di akhirat mereka beroleh siksaan yang besar," ${ }^{67}$ atau ayat tentang hukuman qisas, dalam surah Al-Baqarah ayat 178, "Hai

\footnotetext{
65 Ibid., 683.

66 Ibid., 212.

67 Ibid., 211.

68 Ibid., 52.
}

orang-orang yang beriman diwajibkan atas kamu qishash berkenaan dengan orangorang yang dibunuh; orang merdeka dengan orang merdeka, hamba dengan hamba, dan wanita dengan wanita. Maka barangsiapa mendapat suatu pemaafan dari saudaranya, hendaklah (yang memaafkan) mengikuti dengan cara yang baik, dan hendaklah (yang diberi maaf) membayar (diat) kepada yang memberi maaf dengan cara yang baik (pula)..." ${ }^{18}$

Maka jika ayat di atas dipahami secara literal dan tekstual atau kaku tanpa melihat konteks sejarah dan peraturan perundangundangan di Indonesia akan menumbuhkan sikap intoleransi pada pemeluknya yang berujung pada tindak kekerasan. Praktik semacam itu pernah terjadi pada salah satu kelompok yang diidentifikasi radikal di Indonesia. Saat mereka membantu umat Islam yang konflik di Ambon, salah seorang anggotanya mengaku telah melakukan perzinaan dengan penduduk setempat. Sesuai dengan ayat di atas, maka akhirnya anggota laskar tersebut dihukum rajam, dengan dilempari batu sampai meninggal, padahal Indonesia tidak menerapkan hukum rajam. ${ }^{69}$ Respon para ulama saat itu juga tidak sependapat dengan cara-cara yang dilakukan kelompok tersebut. Di antaranya sebagaimana diberitakan Gatra, K.H. Umar Shihab dari Majelis Ulama Indonesia (MUI) menyatakan bahwa pemberlakuan hukum Islam itu harus mengikuti satu mekanisme undang-undang yang disahkan negara karena yang diperintahkan menegakkan hukum adalah pemerintah sebagai pemegang kekuasaan. ${ }^{70}$

\footnotetext{
69 Mujib Rahman dan Herry Muhammad, "Eksekusi Rajam Untuk Pezina Ambon," Gatra Nomor 24 Beredar Senin 30 April 2001, 24.

$70 \mathrm{lbid}$.
} 
Kedua, provokasi. Provokasi adalah sebuah sikap untuk menghasut, memengaruhi dan membangkitkan amarah seseorang atau kelompok dan melakukan tindakan tertentu dari yang menghasut. Biasanya kelompok radikal ini akan membenturkan kebijakankebijakan pemerintah yang dianggap tidak sejalan dengan kepentingan kelompoknya, "Kelompok radikal berusaha meyakinkan masyarakat bahwa kondisi hari ini adalah akibat dari sebuah kesalahan fatal karena masyarakat masih menganut ideologi dan sumber hukum yang salah, Pancasila dan UUD 1945," dianggap tidak bersumber dari hukum Allah SWT. Menganggap itu adalah produk penjajah Belanda, jadi tidak akan pernah pro dengan masyarakat, hanya pro terhadap penguasa saja," lanjutnya. Kelompok radikal dengan isu ini berharap bisa memprovokasi masyarakat agar sejalan dengan pemikirannya. Dengan harapan, revolusi dengan mengganti Pancasila dan UUD 1945 dengan konsep khilafah. Kelompok radikal juga selalu mambandingkan proses pelaksanaan aturan di negara RI banyak yang malawan hukum Allah. la mencontohkan dalam Al-Qur'an tidak boleh minum minuman keras, berjudi, berzina dan lain-lain. Sehingga dengan alasan tersebut mereka mencoba untuk mengajak pemboikotan terhadap produkproduk yang dianggap tidak islami, juga merembet pada pemboikotan produkproduk bikinan luar negeri yang dianggap merugikan umat Islam, misal: ajakan untuk menolak atau boikot produk-produk Barat karena dianggap mewakili produkproduknya orang-orang kafir, seperti:

71 Amirullah, "JK Minta Masyarakat Tak Emosional Serukan Boikot Produk Amerika," Tempo.Co, diakses $10 \quad$ Februari 2020 https://nasional.tempo.co/read/1043592/jk-minta-
Starbucks, Coca-cola, KFC, Mc Donalds, dan lain-lain. ${ }^{71}$

\section{Penerapan Metode Dakwah Mujadalah}

Dalam penerapan metode dakwah mujadalah ada dua sasaran objek dakwah, yaitu pelaku radikalisme Islam dan orangorang yang terpengaruh oleh pemikiran para pelaku radikalisme Islam, untuk pelaku radikalisme Islam maka metode dakwah mujadalah berfungsi sebagai terapi penyembuhan, tetapi untuk yang sekadar terpengaruh maka metode dakwah mujadalah berfungsi sebagai pencegahan. Objek dakwah yang pertama adalah orang Islam yang mempunyai pikiran yang kaku, sempit, dan tekstual dalam memahami Islam, slogan pemurnian ajaran Islam dengan kembali kepada Al-Qur'an dan sunah Nabi dimaknai secara tekstual dan juga harus sesuai dengan abad keenam Masehi tanpa melihat kondisi sosial budaya dan permasalahan saat itu (konteks) peristiwa yang ada, serta bersifat eksklusif dalam memandang agama-agama lainnya. Sedangkan perilaku radikalisme Islam yang lain adalah gerakan Islam yang menggunakan berbagai bentuk kekerasan dalam rangka perjuangan untuk mendirikan 'Negara Islam'.72 Dari kelompok yang mencita-citakan negara Islam atau khilafah islamiah tersebut ada yang memandang pemerintah dianggap sebatas tidak berpihak pada Islam dan harus didakwahi tetapi ada yang berpemahaman pemerintah sudah kafir dan harus diubah dengan negara Islam.

masyarakat-tak-emosional-serukan-boikot-produkamerika

72 M. Imdadun Rahmat, Arus Baru Islam Radikal: Transmisi Revivalisme Islam Timur Tengah ke Indonesia, 53. 
Kelompok-kelompok inilah yang menjadi objek dari metode dakwah mujadalah.

Umat Islam di Indonesia meskipun mayoritas beragama Islam tetapi tidak sama dengan memiliki kemauan dalam menjalankan syariat-syariat Islam dalam praktik kehidupan sehari-hari. Dari $88 \%$ jumlah umat Islam di Indonesia hanya $16 \%$ yang bersedia memilih keseluruhan parpol Islam. ${ }^{73}$ Sehingga kalau dalam dakwah lebih menekankan simbol-simbol Islam, seperti pakaian/perda-perda syariat Islam, dan praktik-praktik hukum Islam seperti berzina harus dirajam atau didera, mencuri harus dipotong tangannya, maka ajaran Islam akan ditakuti oleh umat Islam itu sendiri, aktivitas dakwah hendaknya lebih menekankan pada sisi substansial ketimbang mendahulukan simbol/baju agama, ${ }^{74}$ yaitu dengan mengutamakan sistem penanaman "nilai-nilai Islam" ke dalam jiwa manusia. Tidak perlu mendahulukan "simbol dan jargon keislaman" dalam berdakwah. Dari pendasaran data di atas sangatlah jelas bahwa meskipun mayoritas bangsa Indonesia memeluk agama Islam tetapi tidak sama dengan secara mayoritas setuju kalau Indonesia berdasarkan syariat Islam atau bahkan menjadi negara Islam, apalagi Islam yang ditampilkan adalah Islam yang keras, kaku, dan saling menghujat, serta berperilaku intoleran terhadap yang berbeda aliran. Maka ini sebenarnya berpotensi gerakan Islam radikal makin membuat umat Islam pada umumnya menjadi islamofobia.

Untuk gambaran materi dakwah dalam metode dakwah mujadalah, sebenarnya ada dalam cerita-cerita yang ada di Al-Qur'an,

\footnotetext{
${ }^{73}$ Abdul Munir Mulkhan, dan Bilveer Singh, Demokrasi di bawah bayangan mimpi $N-11,110$.
}

bagaimana kisah perdebatan Nabi Ibrahim, Nabi Musa, dan Nabi Muhammad sudah menunjukkan bagaimana metode mujadalah itu bekerja, namun memang objeknya adalah para penguasa yang belum memercayai nilai-nilai ketauhidan, tetapi secara substansi bagaimana metode mujadalah itu bekerja adalah sama, yaitu mencoba mempertanyakan kembali (dialektika) dan menggunakan logika-logika dasar serta pengetahuan ilmiah dalam membongkar kesalahan berpikir mereka.

Contoh pertama, penerapan metode dakwah mujadalah dalam memaknai ayatayat jihad dalam Al-Qur'an. Ayat-ayat tentang jihad, tentang perang, dan tentang perilaku orang-orang kafir dan nonmuslim seperti disinggung sebelumnya, maka para kelompok Islam radikal memaknai ayat-ayat itu secara tekstual bahwa perintah jihad berarti perintah untuk mengangkat senjata dan berperang melawan kaum yang memusuhi Islam, dan penafsiran mereka tentang ayat-ayat tersebut adalah tunggal tidak dimaknai yang selainnya. Metode mujadalah mencoba untuk mempertanyakan kembali makna ayat-ayat jihad tersebut, dengan pendekatan logika dan data-data sejarah serta ilmu pengetahuan yang selainnya, sehingga diharapkan mereka mau untuk kembali memikirkan/meragukan kebenaran pemahamannya dan dapat diberikan pemahaman-pemahaman baru, yang lebih relevan dengan kondisi saat ini dan universal dalam memaknai ayat-ayat jihad tersebut.

Contoh kedua, penerapan metode dakwah mujadalah dalam memaknai pemahaman tentang riba yang menyamakan dengan

\footnotetext{
${ }^{74}$ Zuly Qadir, Syariah Demokratik, Pemberlakuan Syariah Islam di Indonesia, 20.
} 
bunga bank. Peristiwa-peristiwa riba yang terjadi pada zaman Rasul mereka samakan dengan bank-bank yang konvensional memberikan bunga, dan mereka berpendapat harusnya menggunakan bank syariah, maka metode mujadalah mencoba mempertanyakan kembali konsep tersebut dengan pendekatan logika, sejarah, serta ilmu-ilmu ekonomi yang berhubungan dengan cara kerja bank konvensional, sampai mereka merasa ragu-ragu dengan konsepnya.

Contoh ketiga, penerapan metode dakwah mujadalah dalm memahami syariat Islam dan negara Islam. Dengan dalil bahwa negara Indonesia mayoritas beragama Islam, maka selayaknya Indonesia menganut ideologi Islam atau negara Islam, seperti yang pernah diproklamasikan Kartosuwiryo pada tahun 1946 dengan mendirikan negara Islam Indonesia, maka dengan pemahaman seperti itu dapat dipertanyakan konteks sejarah saat NII didirikan dengan konteks sekarang apakah sama dan masih relevan, kemudian sejarah pendirian negara Indonesia yang merupakan kesepakatan para pendiri bangsa yang beraneka ragam keyakinan, dengan data-data sejarah, dan logika yang digunakan maka mereka akan menjadi memikirkan/ragu-ragu dengan keyakinannya yang radikal.

Masih banyak tema-tema yang bisa digunakan dalam membongkar pemahaman mereka, dengan membuat mereka ragu-ragu akan pemahamannya karena dibenturkan data-data dengan sumber rujukan yang bisa dipertanggungjawabkan. Paling tidak mereka akan memikirkan kembali bahwa data atau pemahaman mereka itu benar atau salah, baru setelah itu bisa diberikan data-data pembanding. Hal lain yang terpenting adalah etika dakwah dalam memperlakukan mereka sebagai bagian dari sesama muslim. Orientasi mujadalah adalah untuk mencari kebenaran serta pemecahan masalah umat Islam yang ada, sehingga dengan itu akan menemukan suatu titik kebenaran yang sama.

\section{Kesimpulan}

Islam radikal di Indonesia tidak hanya sebuah gerakan dakwah tetapi mereka juga gerakan ideologis, dengan jalan dakwah yang kaku, keras, dan cenderung menghalalkan segala cara dengan anggapan bahwa selain kelompoknya dan yang tidak mau menerima pendapatnya adalah sesat. Mereka lebih mengutamakan simbolsimbol Islam dan berpandangan secara tekstual atau literal dalam menjalankan nilai-nilai Islam daripada nilai-nilai yang universal yang ada pada ajaran Islam itu sendiri, seperti berlaku adil, bersikap jujur, menghormati hak orang lain, dan menjaga kehormatan sesama muslim. Pemahaman Islam radikal di Indonesia tidaklah mungkin diselesaikan dengan jalan kekerasan atau bermain dengan peraturan-peraturan saja, karena ada persoalan yang bersumber dari pemahaman yang salah dan sudah menjadi gerakan ideologis, sehingga dengan kekerasan tidak akan mungkin mencapai titik temu. Metode mujadalah adalah metode debat dengan membongkar paradigma berpikir yang keliru. Sebagaimana telah dicontohkan dalam AlQur'an saat metode itu digunakan dalam membongkar kesesatan kaum kafir, dengan mujadalah yang benar dan persiapan yang matang selama orientasi debat tersebut adalah mencari kebenaran, maka metode mujadalah ini akan berhasil membongkar doktrin-doktrin pada pemahaman Islam 
radikal. Dan yang terpenting dalam metode mujadalah ini bahwa subjek dakwah tidak boleh menghina atau merendahkan lawan diskusinya, agar mereka tidak resistan atau menutup diri dari kebenaran, sehingga perlu cara-cara yang bil hikmah dan mau'idzah hasanah dalam bermujadalah.

\section{Bibliografi}

Abdullah, Anzar. "Gerakan Radikalisme dalam Islam: Perspektif Historis." ADDIN, Vol. 10 No. 1 (2016): 1-28

Al-Qaradawi, Yusuf. Menuju Pemahaman Islam Yang Kaffah; Analisis Komprehensif tentang Pilar, Karakteristik, Tujuan, dan Sumber-Sumber Acuan Islam. Jakarta: Insan Cemerlang, 2003.

Amirullah. "JK Minta Masyarakat Tak Emosional Serukan Boikot Produk Amerika." Tempo.Co. https://nasional.tempo.co/read/1043592/jk-minta-masyarakat-tak-emosional-serukanboikot-produk-amerika

Darmawan, Budi. "Sejarah Berdirinya Muamalat, Bank Syariah pertama di Indonesia." EkonomiIslam.com. https://ekonomi-islam.com/sejarah-berdirinya-muamalat-bank-syariah-pertamadi-indonesia/

Departemen Agama RI, Al-Qur'an dan Terjemahnya dengan Translasi Arab-Latin. Semarang: Karya Toha Putra Semarang, 1998

Fealy, Greg. Jejak Kafilah: Pengaruh Radikalisme Timur Tengah di Indonesia. Bandung: Mizan, 2005.

Halim, Devina. "Polri: Penusuk Wiranto Menyuruh Anaknya Melakukan Serangan ke Polisi." $\begin{array}{lll}\text { Kompas.com. } & \text { Desember } & 2019 .\end{array}$ https://www.kompas.com/nasional/read/2019/2019/10/17/18091901/polri-penusukwiranto-menyuruh-anaknya-melakukan-serangan-ke-polisi.

Jahroni, Jamhari Jajang. Gerakan Salafi Radikal di Indonesia. Jakarta: Raja Grafindo Persada, 2004.

Karyono Wibowo. "Selain di Islam Kelompok Radikal Juga Ada di Agama Lain." merdeka.com. Februari 19, 2018. https://m.merdeka.com/peristiwa/selain-di-islam-kelompok-radikal-juga-ada-diagama-lain.html

Latif, Yudi. Inteligensia Muslim dan Kuasa. Jakarta: Democracy Project, Yayasan Abad Demokrasi Indonesia, 2012.

Ma'rif, Ahmad Syafii. Islam dan Politik: Teori Belah Bambu, Masa Demokrasi Terpimpin (19591965). Jakarta: Gema Insani Press, 1996.

"Mahfud MD Sebut Radikalisme tak identik dengan agama tertentu." CNN Indonesia, 31 Desember 2019. https://m.cnnindonesia.com/nasional/20191031200409-20-444673/mahfud-mdsebut-radikalisme-tak-identik-dengan-agama-tertentu

McLaughlin, Brian P. and Amelie Rorty. Perspectives on Self-Deception. London: University of California Press, 1988.

Mila. "5 Sunnah Rasulullah Dalam Berpakaian." Islampos. November 21, 2019. www.islampos.com/75509-75509/amp/ 
Munawir, A.W. Kamus Al Munawir Arab Indonesia Terlengkap. Surabaya: Pustaka Progressif, 1997.

Muhyidin, Asep. Dakwah Dalam Perspektif al-Qur'an. Bandung: Pustaka Setia, 2002.

Mulkhan, Abdul Munir dan Bilveer Singh. Demokrasi di Bawah Bayangan Mimpi N-11: Dilema Politik Islam Dalam Peradaban. Jakarta: Kompas, 2011.

Nashir, Haedar. Islam Syariat: Reproduksi Salafiyah Ideologis di Indonesia. Bandung: Mizan,,2013.

Qodir, Zuly. Syariah Demokratik: Pemberlakuan Syariah Islam di Indonesia. Yogyakarta: Pustaka Pelajar, 2004.

. "Gerakan Salafi Radikal dalam Konteks Islam Indonesia: Tinjauan Sejarah." Jurnal Islamica, Vol. 3, No. 1, (2008): 10-12.

Rahmat, M. Imdadun. Arus Baru Islam Radikal: Transmisi Revivalisme Islam Timur Tengah ke Indonesia. Jakarta: Erlangga 2005.

Reno, Muhammad. ISIS: Kebiadaban Konspirasi Global. Bandung: Penerbit Noura Books, 2014.

Rahman, Mujib dan Herry Muhammad. "Eksekusi Rajam Untuk Pezina Ambon." Gatra, Nomor 24 (Senin 30 April 2001).

"Serangan Bom di Tiga Gereja Surabaya: Pelaku Bom Bunuh Diri 'Perempuan yang Membawa Anak'," BBC News Indonesia. 8 Februari 2020 https://www.bbc.com/indonesia/indonesia-44097913

"SKPP Muhammadiyah No. 149/Kep/I.0./2006 tentang Kebijakan Pimpinan Pusat Muhammadiyah Mengenai Konsolidasi Organisasi dan Amal Usaha Muhammadiyah." Muhammadiyah.or.id. www.muhammadiyah.or.id/id/download-peraturan-7.html

Syamhudi, M. Hasyim. Filsafat Dakwah. Yogyakarta: Pustaka Ilmu, 2014.

Taufiq Siddiq. "Daerah dengan Perda Syariah dan Injil dari Aceh hingga Papua" Tempo.co. https://nasional.tempo.co/read/1147430/daerah-dengan-perda-syariah-dan-injil-dari-acehhingga-papua

Tim Kompas. "Satu Dekade Polisi Jadi Sasaran Teror." Koran Kompas. Kamis, 14 November 2019.

Ummah, Sun Choirol. "Akar Radikalisme Islam Di Indonesia." Humanika, Vol. 12 No. 1 (2012): 112124. https://doi/org/10.21831/hum.v12i1.3657

Wahid, Abdurrahman (Editor). Ilusi Negera Islam: Ekspansi Gerakan Islam Transnasional di Indonesia, Jakarta: The Wahid Institute, 2009

Zada, Khamami. Islam Radikal. Pergulatan Ormas-ormas Islam Garis Keras di Indonesia. Jakarta: Penerbit Teraju, 2002. 
Agung Teguh P

326 | INTELEKSIA - Jurnal Pengembangan Ilmu Dakwah 